\section{Use of a New Fibrin Sealant and Laser Irradiation in the Repair of Skull Defects in Rats}

Amilton latecola' ${ }^{1}$, Benedito Barraviera ${ }^{2}$, Rui Seabra Ferreira Junior ${ }^{2}$, Geovane Ribeiro dos Santos ${ }^{1}$, José Ivanildo Neves ${ }^{3}$, Marcelo Rodrigues da Cunha ${ }^{1}$
'Department of Morphology and Pathology, FMJ - Medical School of Jundiai, Jundiai, SP, Brazil ${ }^{2}$ CEVAP/UNESP - Center for the Study of Venomous Animals, Botucatu, SP, Brazil ${ }^{3}$ International Center for Research, CIPE/A.C. Camargo Hospital, São Paulo, SP, Brazil

Correspondence: Prof. Dr. Marcelo Rodrigues da Cunha, Rua Francisco Telles, 250, 13202-550 Jundiaí, SP, Brasil. Tel: +55-11-4587-1095. e-mail: cunhamr@hotmail.com

Key Words: system fibrin sealant, grafts, laser, bone.

\section{Introduction}

Autogenous bone grafting is used for the treatment of congenital deformities, traumatic injuries and tumors of the craniomaxillofacial skeleton because of its clinical advantages, such as compatibility of the new tissue formed at the implant site, absence of immune rejection, supply of osteoprogenitor cells that immediately stimulate bone regeneration, and biomechanical ability to withstand loads. However, the difficulty in obtaining sufficient amounts of autogenous bone may limit its application $(1,2)$. In this respect, the use of biomaterials in combination with autogenous bone grafts has shown to be a good alternative to fill completely bone defects. In addition, laser therapy contributes to accelerate the fracture repair by improving osteogenesis (3).

Biomaterials used for tissue healing should be inert, degradable and resorbable, and should favor cell growth without any associated complication. Various materials fulfilling these requirements have been tested for bone reconstruction (4). The healing and regenerative effects of fibrin sealant in the cardiovascular (5), urinary (6) and ophthalmic (7) systems have been demonstrated in the literature. Commercially available fibrin sealants are produced from bovine thrombin and human fibrinogen. However, their disadvantages include the risk of transmitting infectious diseases and the development of antibodies against bovine thrombin. Thus, a new fibrin sealant derived from an enzyme obtained from snake venom and fibrinogen extracted from large animals was developed for tissue regeneration. This new fibrin sealant acts as a substrate for cell growth and shows total biocompatibility, as demonstrated by researches in animals and humans (812). Therefore, the objective of the present study was to evaluate the osteogenic and healing capacity of this new fibrin sealant in combination with autogenous bone grafts and laser irradiation during the healing of experimentally induced skull defects in rats.

\section{Material and Methods}

Fibrin sealant is manufactured from the serine protease from a snake venom (Crotalus durissus terrificus) and fibrinogen cryoprecipitate obtained from blood extracted from adult buffaloes. These components were reconstituted in liquid generating a fibrin network (12).

Thirty male Wistar rats (Rattus norvegicus), 15 weeks old, weighing $370 \mathrm{~g}$, were obtained from the animal care facility of the Medical School of Jundiai, SP, Brazil. For the surgery, animals were anesthetized by an intramuscular administration of a mixture (1:1) of xylazine hydrochloride and ketamine hydrochloride (Agronova, Jundiaí, SP, Brazil) at $1 \mathrm{mg} / \mathrm{kg}$ body weight. After shaving, the skin of the calvaria was sectioned longitudinally to expose the parietal bones. The periosteum was displaced with appropriate surgical material and a 5-mm defect was created in the left parietal bone with a hand-held trephine drill, exposing the encephalic dura mater. The bone defect was filled with a 3-mm bone fragment removed from the right parietal bone, which served as autogenous bone graft and implanted in the center of the receptor bone defect (Fig. 1). Immediately after surgery, gallium-arsenide laser (BIOSET, Campinas, SP, Brazil) irradiation was applied to the recipient area at 
an intensity of $5.0 \mathrm{~J} / \mathrm{cm}^{2}$ and $7.0 \mathrm{~J} / \mathrm{cm}^{2}, 5$ times per week. Pulsed laser spots (wavelength of $940 \mathrm{~nm}$ ) were applied 10 times, each application lasting $11.5 \mathrm{~s}$.

The animals were divided into 6 groups of 5 animals each: autogenous graft (G1 - control), autogenous graft and laser $5 \mathrm{~J} / \mathrm{cm}^{2}(\mathrm{G} 2)$, autogenous graft and laser $7 \mathrm{~J} / \mathrm{cm}^{2}$ (G3), autogenous graft and fibrin sealant (G4), autogenous graft, fibrin sealant and laser $5 \mathrm{~J} / \mathrm{cm}^{2}$ (G5), autogenous graft, fibrin sealant and laser $7 \mathrm{~J} / \mathrm{cm}^{2}$ (G6). After 6 weeks, the animals were sacrificed in a gas chamber after general anesthesia and the skulls were removed and submitted to conventional radiologic and histologic analysis with hematoxylin-eosin to observe new bone formation. All specimens were radiographed using a $\mathrm{CR}-30 \mathrm{X}^{\circledast} \mathrm{AGFA} \mathrm{x}$-ray unit (Agfa HealthCare, Greenville, SC, USA) with $200 \mathrm{~mA}$ and $40 \mathrm{kV}$.

The volume of newly formed bone in the recipient area was calculated using a 100-point quadrilateral grid system coupled to the eyepiece of a light microscope. Newly formed bone was quantified according to the Delesse principle, using the formula $\mathrm{Vv}=\mathrm{Pp} / \mathrm{Pt}(\%)$, where $\mathrm{Vv}$ is the volume density or relative volume, $\mathrm{Pp}$ is the number of points (line intersection) on newly formed bone, and $\mathrm{Pt}$ is the total number of points of the system (13). The results were analyzed by ANOVA and Tukey's test, using the Bioestat 5.0 software. The significant level was set at 5\%.

The study was approved by the Ethics Committee of the Medical School of Jundiai, Brazil, under protocol number 273/11.

\section{Results}

Radiologic analysis showed integrity of autogenous bone graft (Fig. 2). Histologically, immature new bone formation was observed on the surgical site in all groups, but the bone defect was not completely closed. The autogenous graft was not incorporated as indicated by presence of connective tissue in the bone-autogenous graft interface. On the other hand, in the groups receiving the sealant ( $G 4$, $\mathrm{G} 5, \mathrm{G} 6)$ it was evident the prolongation of newly formed bone starting from autogenous grafts and margins of bone defect. In G6, the defect repair was better, promoting a reduction of the autogenous graft-bone interface. The absence of inflammatory cells indicates biocompatibility of the new fibrin sealant (Fig. 3). The percentage (\%) of volume of newly formed bone in the surgical sites of groups ( $\mathrm{G} 1$ to G6) was $8.66 \pm 3.21,9.00 \pm 1.73,17.00 \pm 1.00,24.66 \pm 1.52$, $24.00 \pm 1.00$ e $37.00 \pm 1.00$, respectively, significantly higher in $\mathrm{G} 6(\mathrm{p}<0.05)$.

\section{Discussion}

The osteogenic properties of biomaterials depend on their physical characteristics such as electron distribution, three-dimensional arrangement, molecular conformation, piezoelectric properties and porosity, as well as on their chemical compatibility (14). A promising biomaterial is fibrin sealant, used as a biological glue in different surgical procedures due to its hemostatic and adhesive properties (12). In addition, fibrin sealant can serve as a scaffold for cell proliferation and growth (16). The use of this type of adhesive as a slow-release drug delivery system and as a substrate for cell growth has been suggested (17).

Fibrin sealants are prepared from blood plasma and are used as a biodegradable tissue adhesive. The objective of its application in different surgical situations is to reduce or prevent bleeding from parenchymatous structures. The mechanism of action of these products consists of a crossreaction with clotting factor XIII, which is catalyzed by calcium, with thrombin converting fibrinogen into a strong fibrin network that is mechanically stable and has marked adhesive properties. The biological principles of fibrin
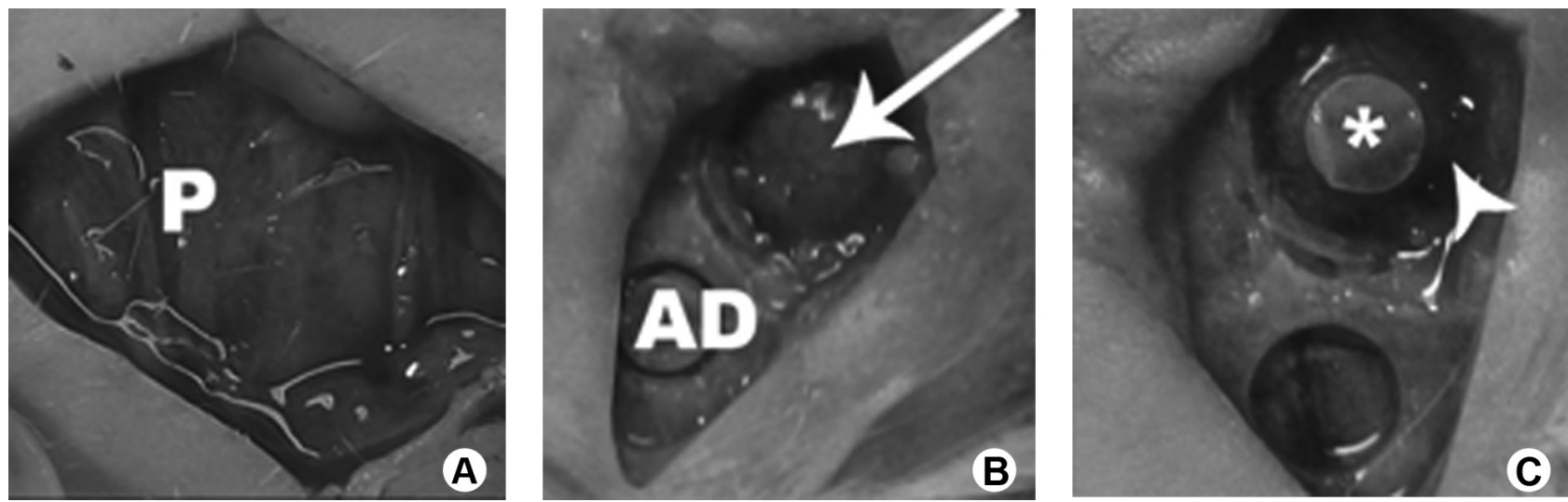

Figure 1. Surgical procedure for creation of a cranial bone defect and radiographs of the skullcap. The parietal bones $(\mathrm{P})$ were exposed $(\mathrm{A})$ and the bone defect (arrow) (B) was filled with autogenous bone graft (asterisk) (C) removed from the autogenous donor site (AD) (B). Note the bone-implant interface (arrowhead) (C). Magnification, 5x. 
sealant are similar to those of the coagulation cascade, resulting in the definitive formation of a fibrin clot (18). Several formulas of fibrin sealant have been developed, varying according to the source of fibrinogen and thrombin
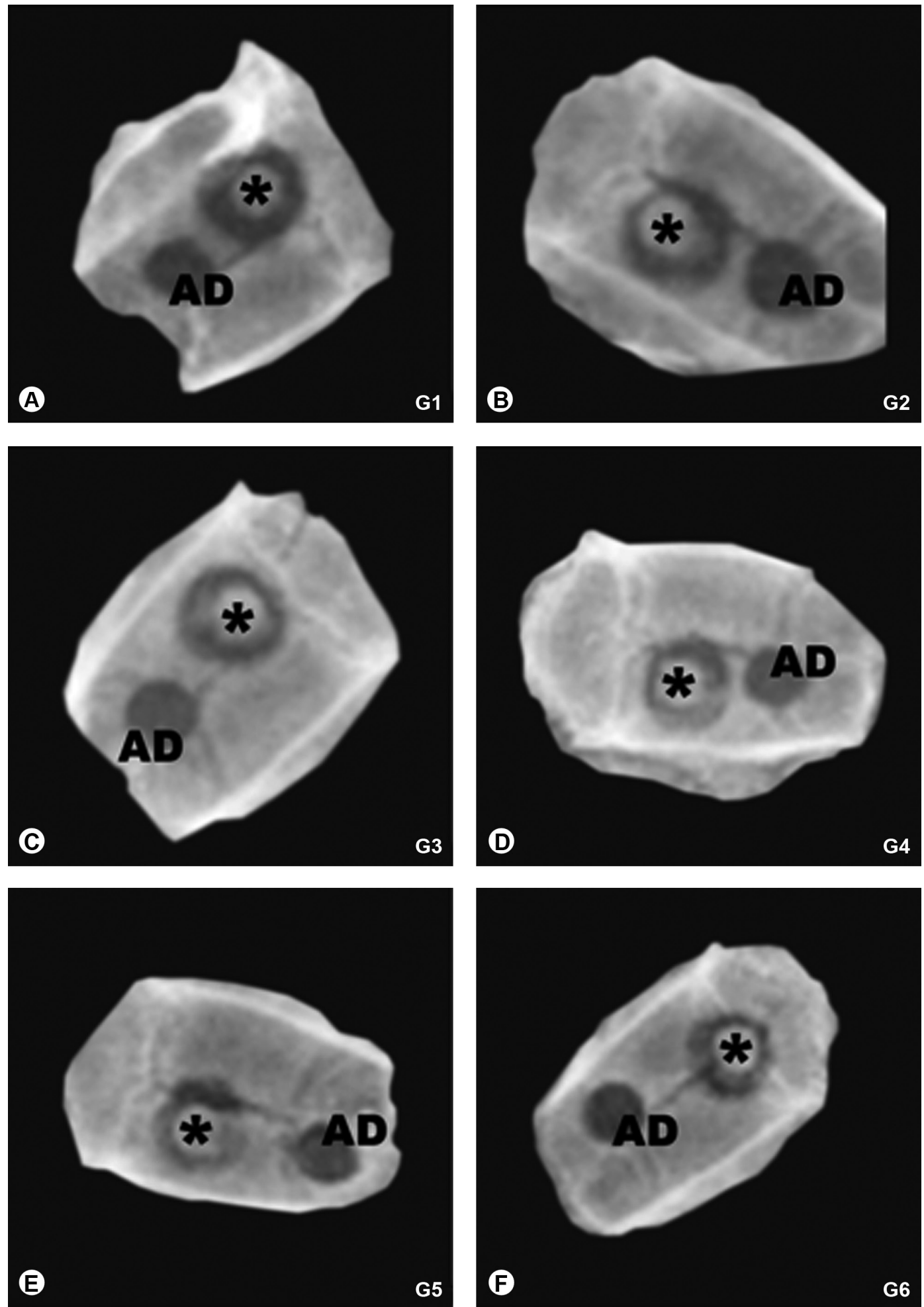

Figure 2. Radiographs of the skullcap showed the implant site of the autogenous bone graft $(*)$ in animals of the studied groups. Note the radiopacity of the autogenous graft and radiolucency of the bone-implant interface due to the presence of connective tissue and bone formation of low atomic weight. $\mathrm{AD}$ : donor site of the autogenous graft. 
snake venom that is more potent than bovine thrombin. This sealant interacts with the enzymatic fraction of snake venom, releasing monomeric fibrin in the presence of calcium and factor XIII which is converted into a polymer with adhesive and sealant properties (19).
In the present study, radiologic and microscopic analysis showed no signs of inflammation, demonstrating biocompatibility of the new fibrin sealant used for bone repair. The absence of inflammatory signs has also been reported by other investigators who used the same

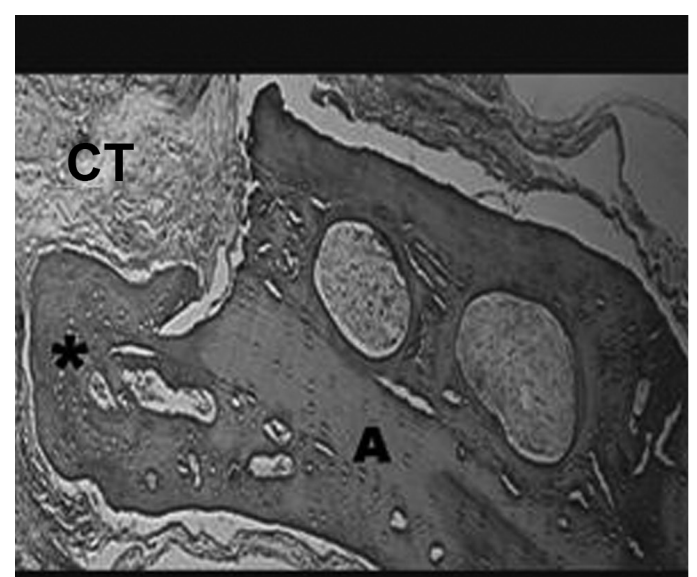

A
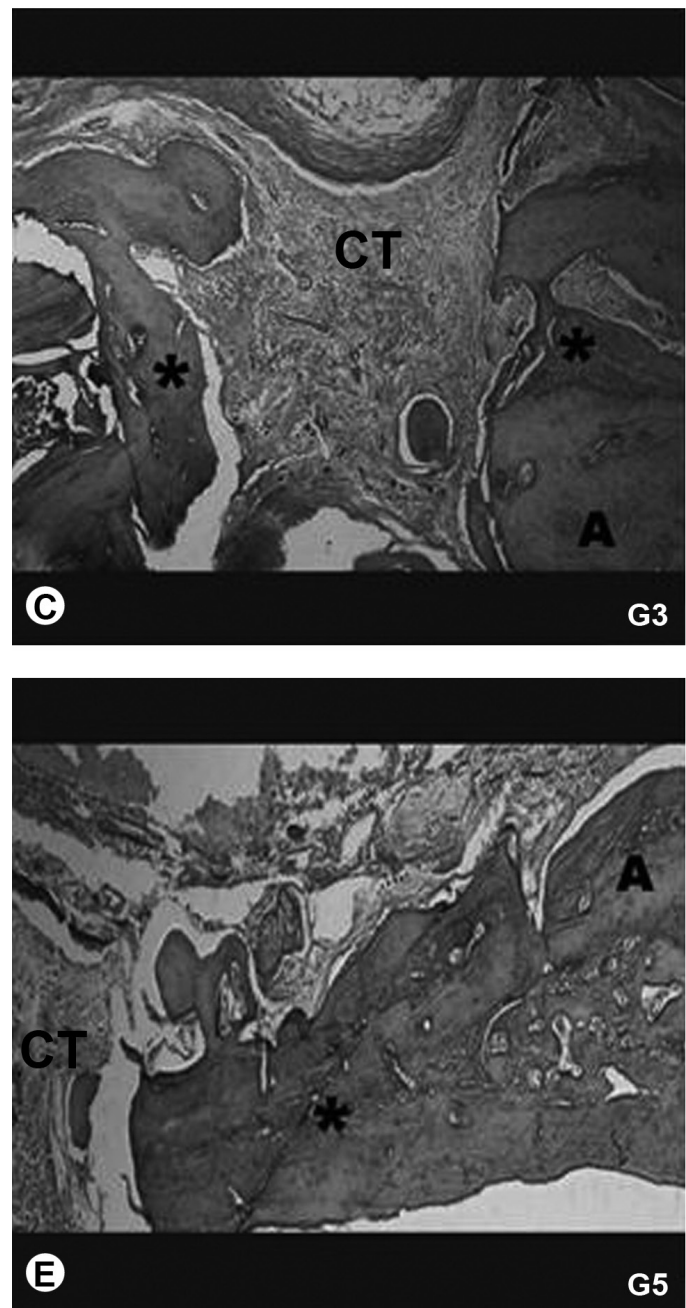
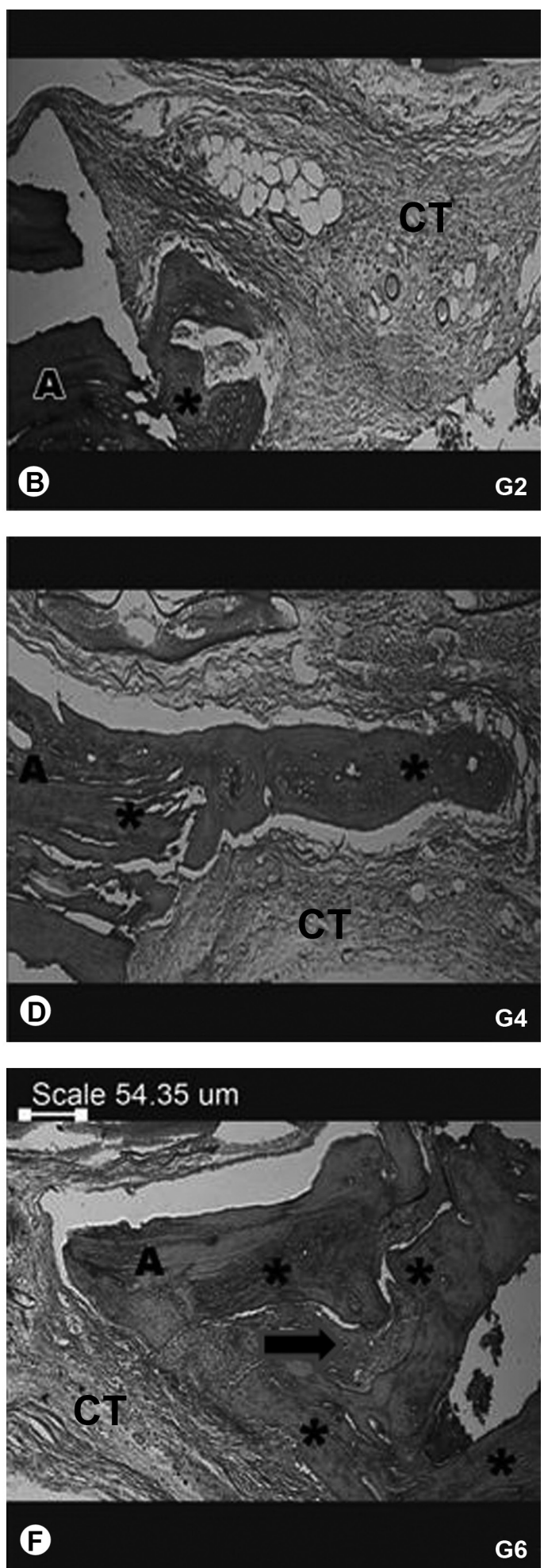

Figure 3. Photomicrographs of the implant site in animals of the groups studied. Note the new bone (*) formed in all groups and projected from autograft graft (A) and margins in bone defect. In G6, note reduction of the autogenous-bone interface (arrow). Connective tissue (CT). Scale bar: $54.35 \mu \mathrm{m}$. 
biomaterial, but for reconstruction of different tissues in humans $(20,21)$. Furthermore, the volume of newly formed bone was greater in groups (G3-G6) treated with the new fibrin sealant derived from snake venom. These microscopic findings support the ability of this new sealant to act as a substrate for bone growth, making it a good resource for stimulating osseointegration of bone grafts. Thus, the fibrin network arrangement of the new sealant was essential for new bone formation. Radiologic analysis did not allow a clear demonstration of new bone formation for being immature and having low atomic weight, as previously described (22).

Gasparoto et al. (23) evaluated the in vitro viability of new fibrin sealant (FS) derived from snake venom as a scaffold for mesenchymal stem cells (MScs). In the results, the FS was able to capture and maintain the MSCs, promoting good cell interaction and the researchers noted accumulation of calcium in cell culture. Thus, the successful use of this new sealant for in vitro research and therapies for regeneration of the venous ulcers (20) and oral mucosa (21) in patients, makes this a viable alternative to be explored in other regenerative therapies. The results of the present study also showed biocompatibility with bone tissue and favorable osteogenic capacity, suggesting the applicability of this new sealant in surgeries for bone reconstruction and may reduce the need for large amounts of autograft.

Different results were described by Okamoto et al. (24), who evaluated the effects of a commercial fibrin adhesive (Tissucol; Immuno A.G., Vienna, Austria) in the bone healing in rat tibias and observed that the sealant did not prevent bone healing. However, they reported that the healing of the experimental defects was qualitatively similar to those observed in the control group that did not receive the sealant.

In addition to the use of synthetic materials, other techniques such as laser therapy have been tested to further accelerate the bone regeneration process and stability of implants. Low-power laser irradiation has been shown to stimulate bone neoformation by the increased local vascularization, organized collagen fibers and ATP levels. The effect of low-power laser irradiation in bone new formation depends on the intensity, frequency, type and time of application (3). Cunha et al. (25) demonstrated that laser with energy density of $5.0 \mathrm{~J} / \mathrm{cm}^{2}$ was not adequate to accelerate the osteogenic process in bone defect regeneration and this was also observed in the present research. On the other hand, an energy density of $7 \mathrm{~J} / \mathrm{cm}^{2}$ showed a significant effect on new bone formation. G6 presented an intense bone formation and considerable reduction of connective tissue volume at the interface between the margin of the bone defect and the autogenous graft. These results demonstrate the tendency of osteointegration in group $\mathrm{G} 6$ and support the description of Konig Jr (4), who defined osseointegration as a direct bone/graft contact without the interposition of a fibrous tissue. The results of the present study indicate that the osteogenic effect of $7 \mathrm{~J} / \mathrm{cm}^{2}$ laser has an efficiency threshold and that its combination with fibrin sealant derived from snake venom can stimulate graft osseointegration and accelerate the bone repair process. This combination between laser and sealant becomes a therapeutic resource to be further investigated in experimental researches of bone regeneration.

\section{Resumo}

Este estudo avaliou a capacidade osteogênica de um novo selante de fibrina (FS) associado com enxerto ósseo e irradiação laser no reparo ósseo. Defeitos foram criados no crânio de 30 ratos e preenchidos com enxerto autógeno e FS derivado do veneno de cobra. Imediatamente após implantação, foi aplicado laser de baixa potência na área cirúrgica. Os animais foram divididos em grupo controle com autógeno (G1), autógeno e laser $5 \mathrm{~J} / \mathrm{cm}^{2}(\mathrm{G} 2)$, autógeno e laser $7 \mathrm{~J} / \mathrm{cm}^{2}(\mathrm{G} 3)$, autógeno e FS (G4), autógeno, FS e laser $5 \mathrm{~J} / \mathrm{cm}^{2}$ (G5), autógeno, FS e laser $7 \mathrm{~J} / \mathrm{cm}^{2}$ (G6). Os animais foram sacrificados 6 semanas após implante. Resultados mostraram ausência de infiltrado inflamatório no defeito ósseo. Neoformação óssea ocorreu em todos os grupos, entretanto, foi mais intenso em G6. Desta maneira, o FS e laser $7 \mathrm{~J} / \mathrm{cm} 2$ mostraram capacidade osteocondutiva e podem ser um interessante recurso a ser aplicado nas cirurgias de reconstrução óssea.

\section{Acknowledgements}

This study was supported by the CNPq, FAPESP Proc. No. 2009/53846-9, 2009/06280-0, 2010/05769-2, CEVAP (UNESP/BOTUCATU), A. C. Camargo Hospital, NAPED/FMJ.

\section{References}

1. Guskuma $M H$, Hochuli-Vieira $E$, Pereira FP, Junior IRG, Okamoto $R$, Okamoto $\mathrm{T}$, et al.. Bone regeneration in surgically created defects filled with autogenous bone: an epifluorescence microscopy analysis in rats. J Appl Oral Sci 2010;18:346-353.

2. Colombo LRC, Calderoni DR, Rosim ETR, Passeri LA. Biomaterials for orbital reconstruction: a literature review. J Bras Plastic Surgery 2011:26:337-344.

3. Lirani-Galvão AP, Jorgetti V, da Silva OL. Comparative study of how low-level laser therapy and low-intensity pulsed ultrasound affect bone repair in rats. Photomed Laser Surg 2006;24:735-740.

4. Konig Jr B. Implantology and Osseointegration: how to research in ceramics, clinical applications and other materials. 1st ed. São Paulo: Roca; 2010.

5. Borst $H G$, Haverich A, Walterbush G, Maatz W. Fibrin adhesive: an important hemostatic adjunct in cardiovascular operation. J Thoracic Cardiovasc Surg 1982;84:548-533.

6. Kram HB, Ocampo HP, Yamaguchi MP. Fibrin glue in renal and urethral trauma. Urology 1989;33:215-218.

7. Pizzol MMD, Roggia MF, Kwitko $S$, Marinho DR, Rymer S. Use of fibrin glue in ocular surgery. Arch Bras Oftalmol 2009;72:308-312.

8. Viterbo F, Thomazini IA, Giannini MJSM. Peripheral nerve repair with fibrin glue derived from snake venom. Acta Cir Braz 1993;8:suppl 2:85.

9. Sartori FR, Prestes NC, Thomazini IA, Mendes-Giannini MJS. Use of fibrin glue derived from snake venom in the testicular biopsy of rams. J Venom Anim Toxin 1998;4:23-35.

10. Leite VCS, Naresi LE, Arantes HL, Lopes AF. An evaluation by rat colon anastomosis of the efficacy of fibrin glue derived from snake venom. 
J Venom Anim Toxin 2000;6:180-183.

11. Rahal SC, Amaral MSP, Pai VD, Barravieira SRCS, Caporal EHG, Crocci AJ. Effect of fibrin glue derived from snake venom on the viability of autogenous split-thickness skin graft. J Venom Anim Toxins Incl Trop Dis 2004;10:161-172.

12. Barros LC, Ferreira JRS, Barraviera SRCS, Stolf HO, Thomazini-Santos IA, Mendes-Giannini MJS, et al.. A new fibrin sealant from crotalus durissus terrificus venom: Applications in medicine. J. Toxicol Environ Health 2009;12:553-571.

13. Lacerda CAM. What is the interest of normal and pathological morphological research to be quantitative? The example of the stereology. Braz J Morphol Sci 1999;16:131-139.

14. Franco KL, Borges APB, Viloria MIV, Fernandes ES, Fehlberg AF. Pure hydroxyapatite, synthetic hydroxyapatite combined with collagen and liposome-associated synthetic hydroxyapatite as bone substitute in tibial defects caused in dogs: aspects of osseointegration transmitted light microscopy. Arch Bras Med Vet Zootec 2001;53:1-7.

15. Campos DLP, Proto RS, Santos DC, Ruiz RO, Brancaccio N, Gonella HA. Histopathological evaluation of polymethylmethacrylate in rats over a year. J Bras Plastic Surgery 2011;26:189-193.

16. Lasa Jr Cl, Kid RR, Nunez HA, Drohan WN. Effect of fibrin glue and opsite on open wounds in D/B D/B mice. J Surg Res 1993;54:202-203.

17. Spotnitz WD, Prabhu R. Fibrin sealant tissue adhesive - review and update. J. Long Term Eff Med Implants 2005;15:245-270.

18. Duchenese $B$, Tahi $H$, Galand $A$. Use of human fibrin glue and amniotic membrane transplant in corneal perforation. Cornea 2001;20:230-232.

19. Thomazini-Santos IA. Surgical adhesives. J Venom Anim Toxins
2001;7:1-10.

20. Gatti M, Vieira LM, Barraviera B, Barraviera SRCS. Treatment of venous ulcers with fibrin sealant derived from snake venom. J Venom Anim Toxins Incl Trop Dis 2001;17:226-229.

21. Barbosa MDS, Stipp AC, Passanezi E, Greghi SLA. Fibrin adhesive derived from snake venom in periodontal surgery: histological analysis. J Appl Oral Sci 2008;16:310-315.

22. Borges APB, Rezende CMF, Ribeiro MFB. Synthetic hydroxyapatite as bone substitute in experimental defect provoked in the proximal of shinbone of dogs: aspects to the microscopy of transmission. Arch Bras Med Vet Zootec 2000;52:616-620.

23. Gasparotto VPO, Alvarenga FCL, Oliveira ALR, Neto JFL, Guastali MD, Maia $L$, et al.. Viability of fibrin sealant from snake venom as scaffold to rat marrow-derived mesenchymal stem cells. Toxicon 2012;60:95-108.

24. Okamoto T, Alves-Rezende MC, Okamoto AC, Buscariolo IA, Garcia IR Jr. Osseous regeneration in the presence of fibrin adhesive material (Tissucol) and epsilon-aminocaproic acid (EACA). Braz Dent J 1995;6:77-83.

25. Cunha MR, Figueira LA, Issa JPM, Calzzani RAJ, Ribeiro DCP, latecola $A$, et al.. Evaluation of the bone repair in defects grafted with hydroxyapatite and collagen membrane combined with laser therapy in rats. J Laser App 2011;23:1-8.
Received May 23, 2013 Accepted October 11, 2013 